\title{
Corrigendum: The Use of Subscores in Higher Education: When Is This Useful?
}

\author{
Rob R. Meijer ${ }^{1 *}$, Anja J. Boevé ${ }^{1}$, Jorge N. Tendeiro ${ }^{1}$, Roel J. Bosker ${ }^{2}$ and Casper J. Albers ${ }^{1}$ \\ ${ }^{1}$ Faculty of Behavioral and Social Sciences, Psychometrics and Statistics, University of Groningen, Groningen, Netherlands, \\ ${ }^{2}$ Faculty of Behavioral and Social Sciences, Education, University of Groningen, Groningen, Netherlands
}

Keywords: classroom testing, diagnostic testing, formative feedback, test format, subscores, validity open-ended questions

\section{A corrigendum on}

OPEN ACCESS

Edited and reviewed by:

Meryem Yilmaz Soylu,

University of Nebraska-Lincoln,

United States

*Correspondence:

Rob R. Meijer

r.r.meijer@rug.n

Specialty section:

This article was submitted to

Educational Psychology,

a section of the journal

Frontiers in Psychology

Received: 09 February 2018

Accepted: 15 May 2018

Published: 28 May 2018

Citation:

Meijer RR, Boevé AJ, Tendeiro JN Bosker RJ and Albers CJ (2018) Corrigendum: The Use of Subscores in Higher Education: When Is This Useful? Front. Psychol. 9:873. doi: 10.3389/fpsyg.2018.00873
The Use of Subscores in Higher Education: When Is This Useful?

by Meijer, R. R., Boevé, A. J., Tendeiro, J. N., Bosker, R. J., and Albers, C. J. (2017). Front. Psychol. 8:305. doi: 10.3389/fpsyg.2017.00305

In the original article, there was an error: There were a couple of incorrect numbers.

A correction has been made to the RESULTS section Paragraph 2.

Note that the changes had no further effect on any conclusions.

Sinharay (2010) for example, reported an average operational subtest reliability of 0.38 for subtests with an average of 19 items. The PRMSE in estimating the true subtest score from the observed total score $\left(\mathrm{PRMSE}_{x}\right.$ ) was 0.80 for both the conceptual subtest and the factual knowledge subtest.

The original article has been updated.

\section{REFERENCES}

Sinharay, S. (2010). How often do subscores have added value? Results from operational and simulated data. J. Educ. Meas. 47, 150-174. doi: 10.1111/j.1745-3984.2010.00106.x

Conflict of Interest Statement: The authors declare that the research was conducted in the absence of any commercial or financial relationships that could be construed as a potential conflict of interest.

Copyright () 2018 Meijer, Boevé, Tendeiro, Bosker and Albers. This is an open-access article distributed under the terms of the Creative Commons Attribution License (CC BY). The use, distribution or reproduction in other forums is permitted, provided the original author(s) and the copyright owner are credited and that the original publication in this journal is cited, in accordance with accepted academic practice. No use, distribution or reproduction is permitted which does not comply with these terms. 